DOI https://doi.org/10.18551/rjoas.2017-09.40

\title{
QUALITY LOSS ANALYSIS OF CAPTURE FISHERIES IN THE GULF OF TOMINI REGION, INDONESIA
}

\author{
Miru Sulaeman*, Suparman \\ Faculty of Economics, University of Tadulako, Indonesia \\ *E-mail: sulaimanmiru@yahoo.co.id
}

\begin{abstract}
The post-harvest fish loss in Indonesia is relatively high or about 30 percent. Even Food and Agriculture Organization (FAO) states that the post-harvest fish loss in Indonesia reaches up to 30 percent per year. This study aims to analyze quality loss of capture fisheries in the Gulf of Tomini region-Indonesia. This research used a survey method through direct observation to the fish caught by fishermen. In order to assess the fish loss, organoleptic testing based on the supply chain was done, the sample is four fish. Organoleptic characteristics observation was done through providing an assessment based on the parameter of SNI 012346-2006. The result shows that there is a quality loss of capture fisheries in the Gulf of Tomini region after the fish on the fishing boats (9.0) and landed at the fish port (7.8), fish terminal (6.8), and fish market (5.0). This is caused by the fish catch handling which is still traditional and simple so that fishermen get a loss benefit financially.
\end{abstract}

\section{KEY WORDS}

Post-harvest fish loss, organoleptic, supply chain, Gulf of Tomini.

The post-harvest fish loss in Indonesia is relatively high or about 30 percent. Even Food and Agriculture Organization (FAO) states that the post-harvest fish loss in Indonesia reaches up to 35 percent per year. Looking at the data of Indonesia's fisheries capture in 2014 by 5.8 million tons or about Rp 99 trillion (US $\$ 75$ billion ) so that the value of fish loss reached up to Rp 30 trillion (Expert Assistant to the Indonesian Minister of Marine Affairs and Fisheries, Achmad Poernomo, 2015). The fish loss is a desperate phenomenon which needs special and urgent treatment as able to affect national economic and food defense (The Head of Research and Development of Marine Affairs and Fisheries Ministry, 2015). Ward and Jeffries (2000) states that fish loss covers to physical loss, quality loss, and market loss.

Fish loss condition is also experienced by the community around the Gulf of Tomini since the handling is still traditional. In particular, the Gulf of Tomini has a big potential of capture fisheries, considering the Gulf of Tomini is the largest gulf around the equator area with $\pm 59.500 \mathrm{~km} 2$ length or \pm 6 million hectares and its covers to 4 autonomous regions in Central Sulawesi. The amount of the potential is inversely proportional with the percentage of the poor community in Central Sulawesi reaching up to 13.61 percent, which is the highest number in Sulawesi Island (Central Statistics Body or BPS, 2014). For that matter, an analysis of capture fisheries quality is important to do to know how much the rate of fish loss based on the supply chain, started from fishing until marketing.

\section{LITERATURE REVIEW}

Post-harvest Fish Loss is a total loss value after harvest as a result of physical damage and decline in quality started from the fish was caught until landed at the customer's hand. According to Ward and Jeffries (2000), fish loss explains time period when fish is separated from its living medium. Fish loss consists of several types, namely physical loss, quality loss, and market loss.

Physical loss is the number/weight of fish which is lost or wasted. Physical loss can be caused by several factors, among other, fish damage, attacked by insects, eaten by other animals, over supply and less buyer so fish wasted, stolen and wasted cause of caught (Ward and Jeffries, 2000). 
Quality loss is the discrepancy of the best and worst fish quality value. All the process will fall into decay. Ward and Jeffries (2000) states that the damaged fish will be sold at a low price since its quality has been degraded. Fish categorized damaged are not sold at the same price as fresh fish but will be sold at different market or for another purpose. This layer of fish and ice is not allowed to exceed $50 \mathrm{~cm}$. If it is over, the lowest fish will get a pressure so causes damage or loss weight. Murniyati and Sunarman, 2000).

Market force losses are the most difficult fish loss to be measured. Market losses can be influenced by supply/demand/season and much more. Quality does not fully influence fish price. During harvest moon, the first quality of fish will have a cheap price. Meanwhile, during a hard time, low-quality fish will be more expensive. Losses might happen during the catch, such as the fish fall down from the net or the handling causing a contusion, not using ice during the landed, attacked by insects during the processing and material delay (Ward and Jeffries, 2000).

The fish loss was explored based on the fish supply chain. The main focus of Supply Chain Management (SCM) is to reach the improvement of product quality and efficiency through Supply Chain (SC) of integration (Chin et al., 2006). Effective distribution management has been a key issue in the business known as SCM, which is the latest approach to integrate distribution and production, as one of the concepts of most well-known management in the logistic field (Kiefer and Novack, 1999; Ballou, 2007). SCM is the easiest way to enhance business value by limiting waste through low operational cost (Chasem 1998; Ballou, 2007). By the same token, SCM also can be understood as the management philosophy (Tan et al., 2002, Chan and Qi, 2003). For instance, Lummus and Vokurka (in Ellram and Cooper: 1993) defines SCM as the philosophy combining the management of total expenditures of distribution chain from the supplier to the customer. SCM has been illustrated in many terms; supplier integration; partnerships; main supply management, supplier alliance, supply chain balance (Tan et al., 2002); network path; supplier pipe path management; and value chain management (Croom et al., 2000; Romano and Vinelly, 2001); and as a demand chain (Kotzab and Otto, 2004 in Blackwell and Blackwell, 1999).

Supply Chain Management is an integrated approach philosophy to set total chain from distribution chain of the supplier to the main customer (Ellram dan Cooper, 1990). This management is to connect both upstream and downstream of their operations with suppliers and customers to deliver value to key customers for less cost as an overall supply chain (Martin, 1998; Weber, 2002). An effective supply chain strategy aims to create competitiveness range around the accuracy of goods and services assignments which are competitive, quality, affordable and involving right business partner (Hewitt, 1994; Hobbs et al., 1998; Easton, 2002). Supply Chain Management is a concept which is relatively new in the business world aiming to reach an efficiency at all operational function through the supply in the uncertainty external environment. In several kinds of literature, supply chain management involves a lot of disciplines which simplifies regulation coordination of material and information and the initial supplier to the final user.

\section{METHODS OF RESEARCH}

This research was done with survey method through direct observation to the fish caught by fishermen in the Gulf of Tomini region Indonesia which is the largest Gulf in the equator area with $\pm 59.500 \mathrm{~km} 2$ length or \pm 6 million hectares. The object of this study was fishermen who catch fish in the Gulf of Tomini region.

Fish loss assessment was tested using organoleptic based on the supply chain of 4 samples of fish. Organoleptic characteristic observation was done by giving an assessment based on the parameter of SNI 01-2346-2006 with the weight of 1-9, they were; eyes, gills, body slime surface, meat, smell, and texture ( National Standardization Agency, 2006). 


\section{RESULTS AND DISCUSSION}

Organoleptic assessment of fisheries capture is based on the condition of eyes, gills, body slime surface, meat, smell, and texture. The organoleptic assessment was conducted at 4 points namely, on the fishing boats, fish port, fish terminal, and fish market.

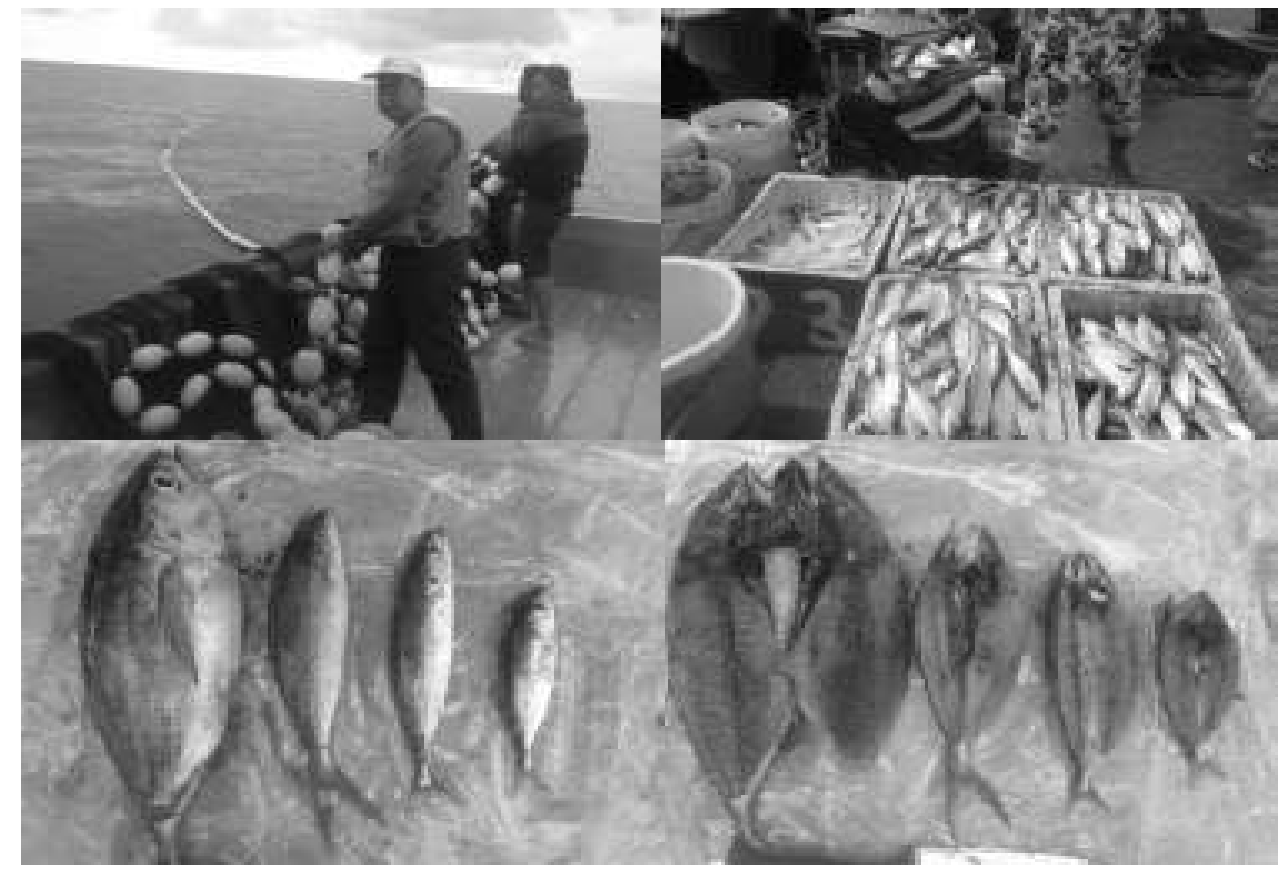

Figure 1 - Capturing Fish in the Gulf of Tomini, Indonesia Source: Survey data, 2017.

Figure 2 illustrates the result of quality loss assessment through organoleptic testing in the fish eyes. According to the data, it can be shown that the average value of the fish on the fishing boats is 9 . This indicates that the fish is truly fresh, having clear eyes, featured eye ball, and clear corneum. Later on, the average value of fish at the fish port, fish terminal and fish market is $8,7,5$ respectively. This condition shows that there is a quality loss from fishing boats to the fish market amounting to 4 or eye ball is slightly concave, grayish pupil, and less clear corneum.

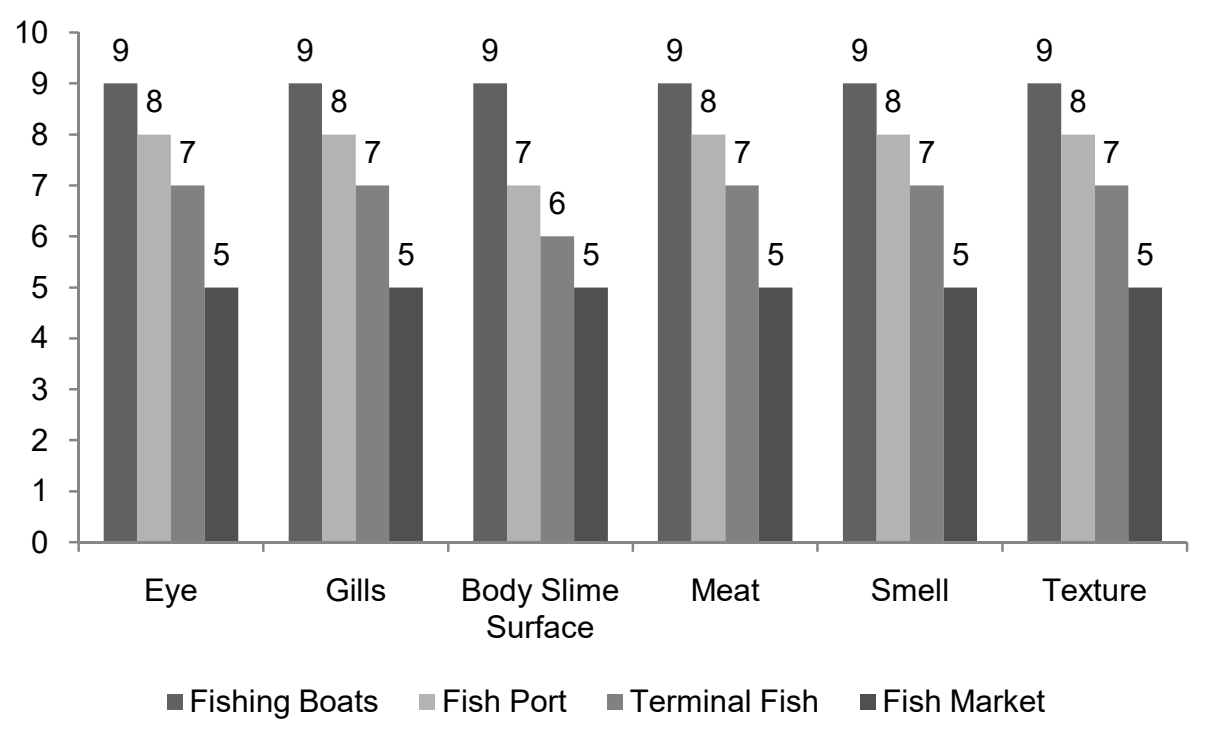

Figure 2 - The Average Value of Organoleptic Testing Result Source: Survey data, 2017. 
The average value of organoleptic testing provided to the gills on the fishing boats is 9 . This indicates that the fish are still fresh since having red brilliant gills without slime. Later on, the average value of fish at the fish port, fish terminal and fish market is 8, 7, 5 respectively. Such this condition shows that there is a quality loss from fishing boat to the fish market amounting to 4 or gills' color changed into brown red and produced slime.

The average value of organoleptic testing provided to the body slime surface on the fishing boats is 9 . This indicates that fish are still fresh since having clear slime layer, transparent, and glossy. The average value of fish when landed at fish port, fish terminal, and fish market is 7, 6, 5 respectively. This indicates that there is a quality loss amounting to 4 from fishing boat to fish market or the slime is dense, the color changes into white and muddy.

The average value of organoleptic assessment conducted to the meat on the fishing boats is 9 . This indicates that fish are truly fresh, having a clear fillet, specific in type, there is no redness along the backbone, the abdominal wall is still in one piece. Later on, the average value of fish at the fish port, fish terminal and fish market is $8,7,5$ respectively. This condition indicates that there is a quality loss from the fishing boat until fish market amounting to 4 or the fish fillet is going to be fade, redness along the backbone, and the abdominal wall is slightly soft.

Organoleptic assessment of fish smell results in an average value of fish on fishing boats by 9 . This indicates that the fish is truly fresh since having a very fresh smell and specific in type. Later on, the average value of fish at the fish port, fish terminal and fish market is $8,7,5$ respectively. This condition shows that there is a quality loss from the fishing boat until fish market amounting to 4 or been smelled ammonia and sour smell of the fish.

The average value of organoleptic assessment of fish texture on fishing boats is 9 . This indicates that the fish are still very fresh, they have a dense texture, elastic if pressed with fingers, hard to tear the meat from the backbone. Later on, the average value of fish at the fish port, fish terminal and fish market is $8,7,5$ respectively. This condition shows that there is a quality loss from fish on fishing boats to fish market by 4 or fish texture is tender, less elastic if pressured with fingers, easy to tear the meat from the backbone.

According to the organoleptic testing above, then the assessment of the weight of each specification (eyes, gills, body slime surface, meat, smell) is accumulated. The result of organoleptic assessment accumulation of fisheries capture in the Gulf of Tomini region is as follows.

Table 1 - Organoleptic Assessment Accumulation of Capture Fisheries

\begin{tabular}{|c|c|c|c|c|c|}
\hline \multirow{2}{*}{ Specification } & \multirow{2}{*}{ Weight } & \multicolumn{4}{|c|}{ Value (Score X Weight) } \\
\cline { 3 - 6 } & & Fishing Boats & Fish Port & Fish Terminal & Fish Market \\
\hline Eye & $16 \%$ & 1.44 & 1.28 & 1.12 & 0.8 \\
\hline Gills & $16 \%$ & 1.44 & 1.28 & 1.12 & 0.8 \\
\hline Body Slime Surface & $16 \%$ & 1.44 & 1.12 & 0.96 & 0.8 \\
\hline Meat & $16 \%$ & 1.44 & 1.28 & 1.12 & 0.8 \\
\hline Smell & $20 \%$ & 1.8 & 1.6 & 1.4 & 1.0 \\
\hline Texture & $16 \%$ & 1.44 & 1.28 & 1.12 & 0.8 \\
\hline Total & $100 \%$ & 9.0 & 7.8 & 6.8 & 5.0 \\
\hline
\end{tabular}

Source: Processed data, 2017

Table 1 above indicates that the fish quality on the fishing boats is truly fresh (9.0), but then the quality losses occurred when fish landed on the fish port (7.8), fish terminal (6.8), and fish market (5.0). This is caused by the fish catch handling which is still traditional and simple so that fishermen get a loss benefit financially.

\section{CONCLUSION}

Quality loss of fisheries capture in the Gulf of Tomini region happened after the fish was caught on the fishing boats (9.0) and landed at the fish port (7.8), fish terminal (6.8), and 
fish market (5.0). This is caused by the fish catch handling is still traditional and simple so that fisherman gets a loss benefit financially. For that reason, it needs an advanced analysis to overcome the fish loss, thus able to reduce financial loss got by fishermen in the Gulf of Tomini region.

\section{REFERENCES}

1. Achmad P. 2015. Susut Hasil Perikanan Tangkap Rp.30 Triliun, Kompas, http://cdn.assets.print.kompas.com/baca/2015/11/12/Susut-Hasil-Perikanan-Tangkap-Rp30-Triliun

2. Ballou, R.H. 2007. The Evolution and Future Of Logistics And Supply Chain Management, European Business Review, Vol. 19 No. 4, pp. 342-8.

3. Blackwell, R. and Blackwell, K. 1999. The Century of The Consumer: Converting Supply Chains Into Demand Chains, Supply Chain Management Review, Fall, pp. 22-3, available at: www. manufacturing.net/scm/index.asp?layout1 4articleWebzine\&articleid 14 CA154949

4. Badan Standarisasi Nasional, 2006. Petunjuk Pengujian Organoleptik dan atau sensori, Jakarta

5. BPS. 2014. Kemiskinan, Jumlah Penduduk dan Persentase Penduduk Miskin di Sulawesi Tengah, http://sulteng.bps.go.id/frontend/Subjek/view/id/23\#subjekViewTab3/accordiondaftar-subjek1

6. Chan, F.T.S. and Qi, H. 2003. An Innovative Performance Measurement Method For Supply Chain Management, Supply Chain Management: An International Journal, Vol. 8 No. 3, pp. 209-23.

7. Chase, C.W. Jr. 1998. The Role Of The Demand Planner In Supply Chain Management, Journal of Business Forecasting, Vol. 17 No. 3, pp. 2-24.

8. Chin, K.S., Yeung, I.K. and Pun, K.F. 2006. Development Of An Assessment System For Supplier Quality Managemen, International Journal of Quality \& Reliability Management, Vol. 23 No. 7, pp. 743-65.

9. Croom, S., Romano, P. and Giannakis, M. 2000. Supply Chain Management: An Analytical Framework for Critical Literature Review, European Journal of Purchasing \& Supply Management, Vol. 2000 No. 6, pp. 67-83.

10. Easton, R. 2002. Seizing The Supply Chain Opportunity In Asia, Ascet, Vol. 4.(The) Economist (1992), April 18, p. 67.

11. Ellram, L.M. and Cooper, M.C. 1990. Supply Chain Management Partnerships And The Shipper-Third Party Relationship, International Journal of Logistics Management, Vol. 1 No. 2, pp. 1-10.

12. Ellram, L.M. and Cooper, M.C. 1993. The Relationship between Supply Chain Management And Keiretsu, The International Journal of Logistics Management, Vol. 4 No. 1, pp. 1-12.

13. Hewitt, F. 1994. Supply Chain Redesign, The International Journal of Logistics Management, Vol. 5 No. 2, pp. 1-9.

14. Hobbs, J.E., Kerr, W.A. and Klein, K.K. 1998. Creating International Competitiveness Through Supply Chain Management: Danish Pork, Supply Chain Management: An International Journal, Vol. 3 No. 2, pp. 68-78.

15. Kepala Badan Penelitian dan Pengembangan Kementerian Kelautan dan Perikanan. 2015. KKP-FAO Kaji Fenomena Penyusutan Pascapanen Perikanan, http://villagerspost.com/todays-feature/kkp-fao-kaji-fenomena-penyusutan-pasca-panenperikanan/

16. Kiefer, A.W. and Novack, R.A. 1999. An Empirical Analysis of Warehouse Measurement Systems in The Context Of Supply Chain Implementation, Transportation Journal, Vol. 38 No. 3, pp. 18-27.

17. Kotzab, H. and Otto, A. 2004. General Process-Oriented Management Principles To Manage Supply Chains: Theoretical Identification 
18. Lummus, R. and Vokurka, R.J. 1999. Defining Supply Chain Management: A Historical Perspective And Practical Guidelines, Industrial Management \& Data Systems, Vol. 99 No. 1, pp. 11-17.

19. Martin, C. 1998 Logistics and Supply Chain Management: Strategies for Reducing Cost and Improving Service, Pitman Publishing, London.

20. Murniyati, S.A., Sunarman. 2000. Pendinginan, Pembekuan dan Pengawetan Ikan . Kanisius, Yogyakarta

21. Romano, P. and Vinelli, A. 2001. Quality Management In A Supply Chain Management Perspective, International Journal of Operations \& Production Management, Vol. 21 No. 4, pp. 446-60.

22. Tan, K.C., Lyman, S.B. and Wisner, J.D. 2002. Supply Chain Management: A Strategic Perspective, International Journal of Operations \& Production Management, Vol. 22 Nos 5/6, pp. 614-31.

23. Ward, A.R. and Jeffries, D.J. 2000. A Manual For Assessing Post Harvest Fisheries Losses. Natural Resources Institute, Chatham, UK. vii + 140 pp. English

24. Weber, M.M. 2002. Measuring Supply Chain Agility In The Virtual Organisation, International Journal of Physical Distribution \& Logistics Management, Vol. 32 No. 7, pp. 577-90.

(c) 2017 by the authors. Licensee RJOAS, Orel, Russia. This article is an open access article distributed under the terms and conditions of the Creative Commons Attribution (CC BY) license: http://creativecommons.org/licenses/by/4.0/ 